\title{
The main properties of fruit offered on the retail market in Hungary
}

\author{
Felföldi, J. \\ University of Debrecen, Department of Agrobusiness Management, Faculty of Applied Economics \\ and Rural Development
}

\begin{abstract}
Summary: The small enterprises of the Hungarian retail market of food and related commodities are in a dismal crisis, many of them got bankruptcy, whereas fruit and vegetables are offered in large shop-chains and supermarkets. Traditional small shops near to the domiciles are still highly esteemed by the population and their lack is regretted especially because of commodities for fresh consumption. For the purpose to evaluate the situation, I planned the comparative study of fruits offered in the retail markets by tracing their origin, quality and prices. From the six shops selected for the study three represent department stores belonging to different chains. Independent entrepreneurs manage the next three shops of vegetables with own suppliers. It was stated that the retail shops offer mainly fruits of Hungarian growers. It is however worthwhile to state that the origin of the produce was frequently not marked. The fruits imported from abroad, apple, pear, peach, were sold at substantially higher prices than those of Hungarian origin.
\end{abstract}

Key words: fruit offered, retail market, price, origin

\section{Introduction}

In Hungary, during the last 15-year-long period, vegetable and fruit production gained much more prestige in the agricultural economy. During the period mentioned, the international market of vegetables and fruits changed a lot. Earlier the ratio of processed to fresh produce was 60:40\%, but at present, the fresh offer increased, and this trends is also sensible in Hungary.

The channels of sale are charged with the task to connect the grower with the consumer regardless of the physical distance between the two participants (just in the neighbourhood or hundreds of kilometres away) (Hoffman, 2000)

The system of distribution changed radically (also on the home markets) with the appearance of department stores and supermarkets in Hungary. The competition of prices was transformed to another type of competition, where not the prices alone are on the stake. The role of security, quality and environmental protection grew, and the professionalism took other form, which altered the path of products also in the agriculture (Ferencz, 2006).

The number of grocer's shops dwindled in Hungary dramatically, and it accelerated in 2004, when 48 new discount markets and 15 hipermarkets have been opened, at the same time, 869 small shops gave up. The concentration is expressed by the bankruptcy of the small enterprises. Within four years, the number of hypermarkets more than doubled, last year 92 hipermarkets existed in the country. Discounts and Supermarkets grew in one year from 752 to 813 (Bajai, 2006).
According to the statistics of the Planet Retail Co., the turnover of the discount shops is still rising in Europe, and it is estimated that it will attain in 2010 the $36 \%$ of the trade. But also the income of discount is increasing, which means that the buyers like it too (Madarászné, 2006b).

The expansion of chain shops is continuing in Hungary (after 2008, the "had discount" appeared), therefore, the concentration of the fruit- and vegetable commerce is an indispensable phenomenon. On the contrary, the Hungarian population is still sticking to the idea to maintain the small shops near to the their domicile especially for the commodities for fresh consumption, i.e. grocers, which offer fruits and vegetables, whereas in the modern trade, the package in trays and boxes is less popular (Madarászné, 2006a). „In the department stores managed by foreign enterprises, fruits imported from the Southern Hemisphere appeared in an excellent package, whereas the apple of the domestic growers was frequently offered only in bulk (lédig), so the image of the domestic horticulture, which should be sympathetic for the buyer, all over Europe, is not exploited in Hungary.” "It seems that in the business policy of the modern department stores the Hungarian apple is not a matter of concern" (Gonda, 2006).

\section{Materials and methods}

The following objectives have been planned in order to clear the unexplored details.

1. The main characteristics of the fruit offered in the retail markets. 
2. The comparison of the fruits offered in different types of shops.

3. We have to check the validity of the often heard contention:

A. The imported foreign fruit is more expensive than that grown in Hungary

B. Department stores sell fruit cheaper than the small shops for vegetables and fruits.

The data are collected in Debrecen, the second largest town of Hungary. During the period between June and February of the next year, i.e. over 8 months, we performed 1150 observations in 6 shops of the retail market. Three of the retail shops belonged to large department stores, whereas the other three were shops of small enterprises, all of them had their own supplier. The observed fruits were: apple, pear, sour cherry, nectarine, peach, apricot and plum. The properties observed were: origin, package, price and quality class. In this study, species, variety, origin and package have been compared and evaluated..

\section{Results}

First, I have registered, what was the origin of the fruits offered in the shops, from Hungary or from another country. The common opinion supposed that in the department stores offer mainly imported fruits.

In the department stores, $62 \%$ of fruits were of Hungarian origin, $14 \%$ of foreign country and $24 \%$ was of unknown origin. This proves the poor attention paid for quality of the shopkeepers. In the department stores, the information upon the origin, price (?), variety was often deficient, sometimes the data were aimed to fruits, which were not exposed at the moment. In one department store, this deficiency occurred repeatedly. In the small shops (Vegetable and fruit shops), $96 \%$ of the fruits was of Hungarian origin, $4 \%$ imported from Italy. The sign of the origin was also in some cases deficient, and the questions were answered evasively. The imported fruits have been scarcely represented in the small shops, that is sure. The small shopkeepers gave always acceptable answers, although the origin was not always obviously signalised.

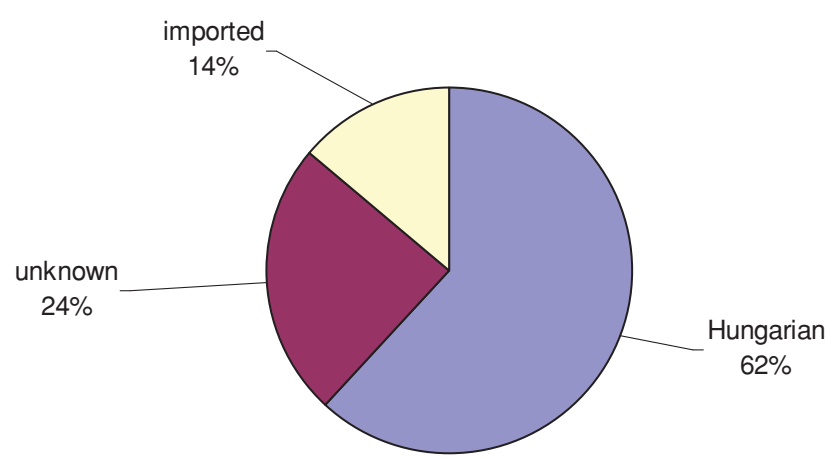

Figure 1. Distribution of the fruits of different origin in the department stores

Source: original calculation
As the fruit of unknown origin are found at considerable rates, we may suppose that they are of foreign origin, $24+14$ $=38 \%$ is already a high rate, but still less than $62 \%$ of fruit of Hungarian origin.

As a result, I stated that most of the fruits: apple, pear, sour cherry, nectarine, peach, apricot and plum are of Hungarian origin.

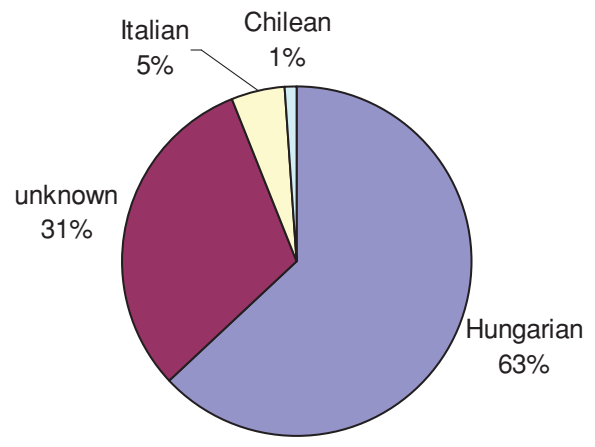

Figure 2. Origin of apples offered in the department stores Source: original calculation

In the department stores the apple offered was of Hungarian origin at $63 \%$, of unknown origin $31 \%$, from Italy $5 \%$, from Chile $1 \%$.

In apple, as well as in all fruits, the dominance of Hungarian origin is clear. The same rates are found in pear, sour cherry, nectarine, peach, apricot and plum. In the small shops, almost $100 \%$ of apples are of Hungarian origin and a small fraction of Italian import. In other fruits, the same was found.

The comparison of the prices was initiated to check the contention that fruits are cheaper in the large department stores shops than in the small shops. The mean prices are compared in Table 1.

Table 1. Comparison of the mean prices of fruits sold in different types of retail shops

\begin{tabular}{|l|c|c|c|c|}
\hline Fruit & $\begin{array}{c}\text { Mean prices in } \\
\text { department } \\
\text { stores } \\
(\text { Ft/kg) }\end{array}$ & $\begin{array}{c}\text { Mean } \\
\text { prices in } \\
\text { small shops } \\
(\text { Ft/kg })\end{array}$ & Significance & $\begin{array}{c}\text { Price } \\
\text { differences } \\
(\text { Ft/kg })\end{array}$ \\
\hline Apple & 217 & 166 & $<0.05$ & 51 \\
\hline Pear & 362 & 436 & $<0.05$ & 74 \\
\hline Nectarine & 374 & 372 & 1 & 2 \\
\hline Peach & 282 & 396 & $<0.05$ & 113 \\
\hline Plum & 167 & 325 & $<0.05$ & 159 \\
\hline
\end{tabular}

Source: original calculation

The average price of apple was $217 \mathrm{Ft} / \mathrm{kg}$ in the department stores, and $166 \mathrm{Ft} / \mathrm{kg}$ in the small shops, which means that the large shops are more expensive. The difference is $51 \mathrm{Ft} / \mathrm{kg}$ significant, therefore not accidental.

In the case of pear, the price was $362 \mathrm{Ft} / \mathrm{kg}$, and 436 $\mathrm{Ft} / \mathrm{kg}$, the difference was in the opposite sense: the small shops offered at higher price the commodity than the large shops, moreover, the difference was larger $(74,13 \mathrm{Ft} / \mathrm{kg})$ and also significant. 
In nectarine, the average prices were $374 \mathrm{Ft} / \mathrm{kg}$ and 372 $\mathrm{Ft} / \mathrm{kg}$ respectively, and not significant. The contention referred to cannot be supported in the case of nectarine.

In peach, the average prices were $282 \mathrm{Ft} / \mathrm{kg}$ and 395 $\mathrm{Ft} / \mathrm{kg}$ in the department stores and in the small shops respectively. Department stores sell cheaper than the small shops. The difference is significant. The difference is even larger that in the case of pear: $113 \mathrm{Ft} / \mathrm{kg}$.

In plum, the average prices were $166 \mathrm{Ft} / \mathrm{kg}$ and $325 \mathrm{Ft} / \mathrm{kg}$ in the department stores and in the small shops respectively. Department stores sell cheaper than the small shops. The difference is significant. The difference is even larger that in the case of peach: $158 \mathrm{Ft} / \mathrm{kg}$.

For sour cherry and apricots, the lack of sufficient data did not facilitate a similar analysis as the former fruit species. This season was not favourable for those fruits.

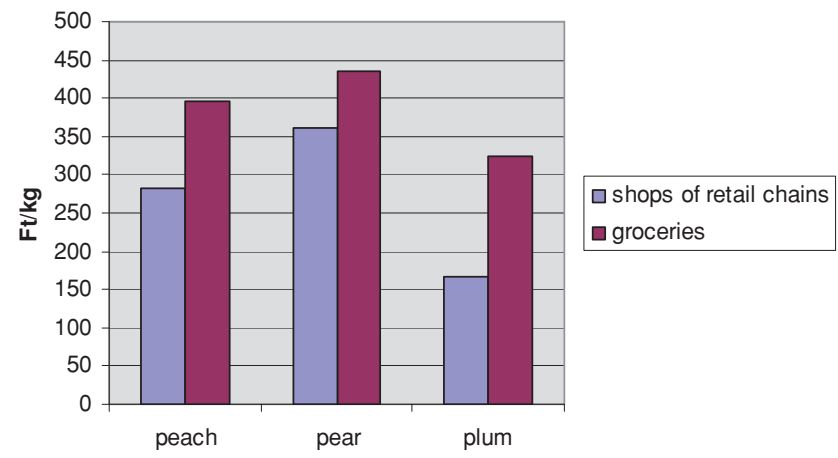

Figure 3. Average prices of peach, pear and plum sold in department stores and in small shops.

Source: original calculation

As shown in Figure 3, in case of the three fruit species, peach, pear and plum, the small shops sell the fruit at higher prices than the large department stores. The difference was largest in plum $(158 \mathrm{Ft} / \mathrm{kg})$, then in peach $(113 \mathrm{Ft} / \mathrm{kg})$ and in pear $(74 \mathrm{Ft} / \mathrm{kg})$.

As a conclusion, we may state that common opinion is valid in the last mentioned three fruit species, but not in the case of apples.

\section{Conclusions and suggestions}

First, I studied the origin of the fruits sold in department stores and in small shops because it was generally believed that the department stores sell mainly imported fruits, and the small shops prefer the trade with fruit of domestic growers. At the same time it turned out that also the department shops do not inform the buyers about the origin of their commodity, neither their quality class, nor the price and the variety, which means a deficiency in the commerce. It happened that the fruits offered have not been provided with due information, and the labels were not properly associated with the offered goods. It is expected to supply the buyer with information of the origin, quality, variety and price of the commodity.

The comparison of prices between the retail shops of different type, department store and small shops, was planned to check the contention widely believed that department stores sell fruit at lower prices than small shops. The results justified that situation in the case of three different fruit species, pear, peach, plum but not in apple. Apple is sold cheaper in small shops.

If the prices of home grown fruits are compared with those of the imported ones we can generally state that the foreign grown fruits are more expensive than the home grown fruits. This is true for apple, pear and peach, they cost much more for the Hungarian consumer than as domestic commodity.

The development of the fruit trade depends largely from the trading traditions, the careful harvested, selected and packed utilising the necessary infrastructure, but the fruit as a commodity should be provided also with the necessary information. However, in Hungary, there is still a lack of commodities of the quality desired by the market, in spite of the favourable conditions. It easily happens that the fruit offered does not fulfil the expectations. The technical conditions of transport, manipulating, packing should be completed with a purposeful marketing organisation in order to meet the requirements of the market.

\section{Acknowledgements}

This paper was supported by the János Bolyai Research Scholarship of the Hungarian Academy of Sciences

\section{References}

Bajai, E. (2006): Két év alatt megszűnt 1800 kisbolt. Zöldség- és gyümölcspiac, 10. (4-5): 18. p.

Ferencz, A. (2006): Keresi a piac az étkezési minőséget. Zöldségés gyümölcspiac, 10. (8-10): 25. p.

Gonda, I. (2006): Mi lesz veled magyar alma?! Debrecen, 2006. 10-14. p.

Hoffmann, I. (2000): Stratégiai marketing. Aula Kiadó Kft., Budapest

Madarászné, F. I. (2006a): A frissgyümölcs-fogyasztás ötletes népszerüsítése. Zöldség- és gyümölcspiac, 10. (6-7): 28. p.

Madarászné, F. I. (2006b): Európa-szerte előretörnek a diszkont áruházak. Zöldség- és gyümölcspiac, 10. (8-10): 25. p. 